\title{
Retrieval of dislodged stents from left main during percutaneous coronary intervention by trapping technique
}

\author{
Usunięcie przemieszczonych stentów z pnia lewej tętnicy wieńcowej \\ w trakcie przezskórnej interwencji wieńcowej techniką trappingu
}

\author{
Santosh Kumar Sinha, Mukesh Jitendra Jha, Divendu Khanra, \\ Avinash Kumar Singh, Ramesh Thakur \\ Department of Cardiology, LPS Institute of Cardiology, G.S.V.M. Medical College, Kanpur, India
}

\begin{abstract}
Dislodgement and embolisation of the new generation of drug eluting stents is a very rare but recognised and potentially serious complication of percutaneous coronary intervention. Various methods, including tangling wire, bioptome, and goose neck snare to surgical removal have been described. Here we report a case of successful retrieval of a deformed coronary stent from left main coronary artery by trapping technique.

Key words: coronary thrombosis, myocardial infarction, retrieval, stent dislodgement, embolisation, sudden death

Folia Cardiologica 2018; 13, 1: 39-43
\end{abstract}

\section{Introduction}

The use of stents during percutaneous coronary intervention is now a routine. Stent dislodgement and embolisation into the systemic or coronary circulation before deployment is a rare but serious complication of coronary stenting. It was not rare when first generation stents were used [1-3]. The consequences could includecoronary thrombosis, myocardial infarction, stroke, perforation and sudden death [4-6]. In the past, manual crimping of stents was associated with a significantly increased risk of stent dislodgement and embolisation. Although these are no more used today, it has still not been completelyeliminated, especially when negotiating tortuous and/or calcified arteries and passage through a previous stent [3]. Furthermore, currently available stents are poorly visible on fluoroscopy before and after the deployment, therefore, in case of embolisation, their retrieval becomes more difficult.

\section{Case report}

A 42-year-old man was admitted with low effort angina Canadian Cancer Society (CCS) class III. Three years earlier, he had suffered an anterior wall myocardial infarction. His risk factors were chronic cigarette smoking and dyslipidaemia. On examination, the pulse rate was 74 beats/min and the arterial blood pressure was $134 / 88 \mathrm{~mm} \mathrm{Hg}$. Other system examinations were within normal limit. Pathological $\mathrm{Q}$ waves, T-wave inversion and poor $\mathrm{R}$ wave progression were present in leads V2-6. An echocardiogram showed mild hypokinesia of LAD Tx with ejection fraction (EF) $52 \%$. The patient was further subjected to tread mill test which was strongly positive for stress induced myocardial ischaemia. Coronary angiogram revealed normal right coronary arteries and left circumflex coronary artery and also chronic total occlusion of left anterior descending artery from ostia, which receivedgrade II Grantham collateral

Address for correspondence: Santosh Kumar Sinha MD, FAESC, Asst. Professor, Department of Cardiology, LPS Institute of Cardiology,

G.S.V.M. Medical College, G.T. Road, Kanpur, Uttar Pradesh 208002, India, fax +91 051225561 99/255 65 21, e-mail: fionasan@rediffmail.com 


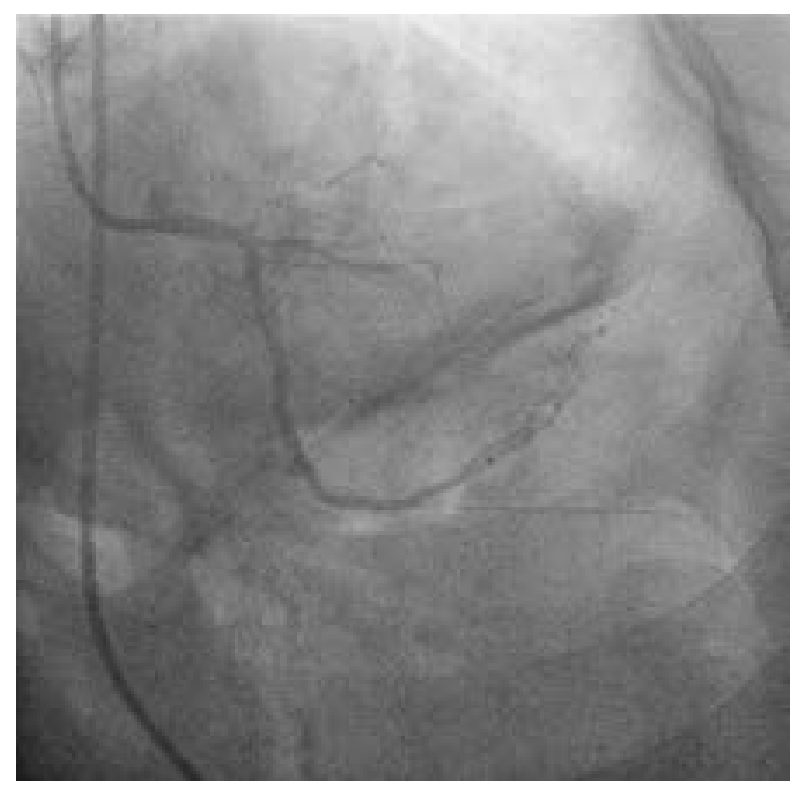

Figure 1. Chronic total occlusion of left anterior descending (LAD) artery from ostia from right coronary arteries (Figure 1, 2A). It was decided to perform percutaneous coronary intervention for the total occlusion after proper consent. Both femoral arteries were punctured and $6 \mathrm{~F}$ Input ${ }^{\mathrm{TM}}$ sheath (Medtronic, USA) was put. Intravenous heparin (100 U/kg) was administered. Left main was hooked with 6 F Launcher ${ }^{\circledR}$ Extra Back Up (EBU) Coronary Guide Catheter (Medtronic, USA). 0.014" $190 \mathrm{~cm}$ Hi-Torque BMW (Abbott Vascular, USA) wire was parked in distal left circumflex artery. 0.014" $190 \mathrm{~cm}$ Fielder XT wire (Asahi Intec, Japan) through FineCross ${ }^{\mathrm{TM}} \mathrm{MG}$ micro catheter (Terumo NJ, USA) was initially tried, but it failed to cross the lesion. As Miracle 6, 9 and 12 (Asahi Intec, Japan) could not cross the lesion, the wire was finally exchanged with 0.014" $190 \mathrm{~cm}$ Conquest Pro 12 (Asahi Intec, Japan) and the lesion was successfully crossed with help of contra lateral injection from right coronary artery to confirm distal true lumen and it was parked distally (Figure 2). The wire was further exchanged with 0.014" $190 \mathrm{~cm}$ Hi-Torque BMW (Abbott Vascular, USA) and FineCross ${ }^{\text {TM }}$ MG micro catheter was removed by Nanto's technique. The lesion was
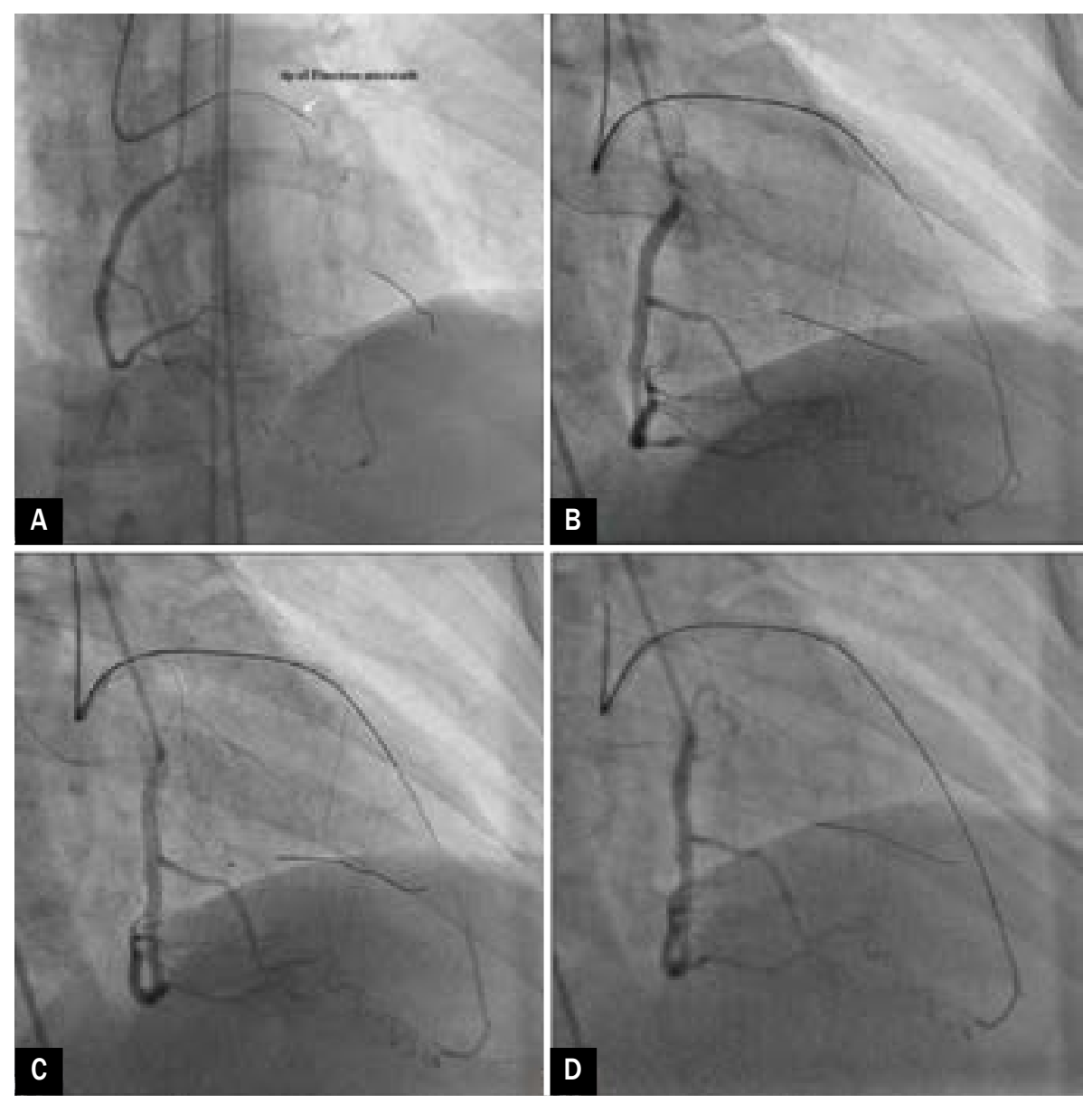

Figure 2AD. Anterior-posterior cranial view showing Conquest-Pro wire being advanced distally in left anterior descending (LAD) with help of contra lateral injection from right coronary artery 


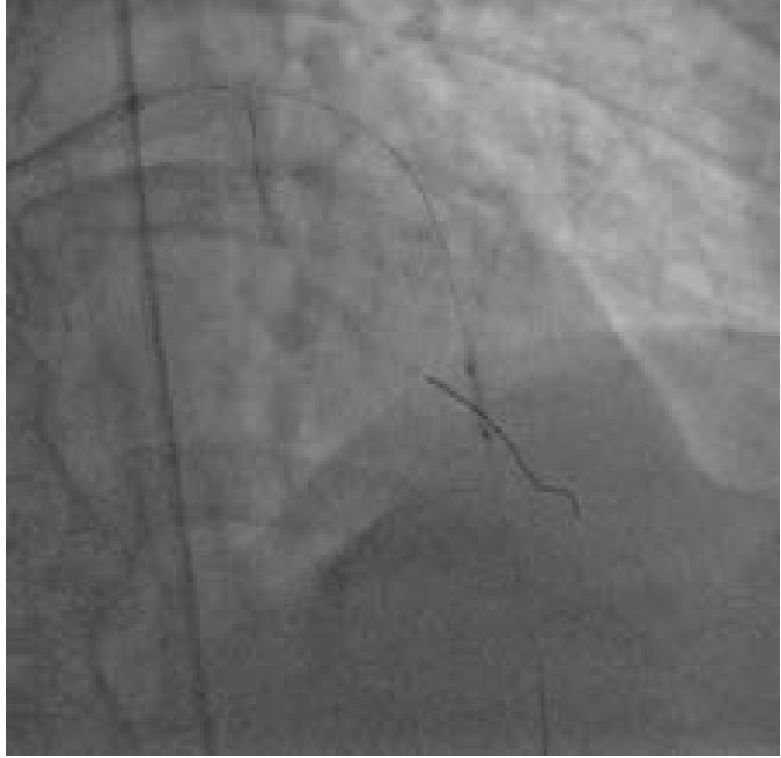

Figure 3. Lesion being dilated with $1.5 \times 10$ Sprinter Legend $^{\mathrm{Rx}}$ Balloon on BMW wire repeatedly dilated with $1.25 \times 6,1.5 \times 10,2 \times 10$ and $2.5 \times$ $\times 10$ Sprinter Legend $^{\mathrm{Rx}}$ Balloon (Medtronic, USA) (Figure 3). Xience Prime $3.5 \times 33 \mathrm{~mm}$ (Abbott Vascular, USA) was tried to place along the lesion, but it was obstructed and further advancement was not possible probably due to heavy calcification along the lesion. Guiding catheter was firmly held and we gave some gentle jerks to the shaft of the stent, but we could not deliver it across the lesion. Finally we have decided to withdraw the stent into the guiding catheter, but the distorted struts was stuck at the mouth of the guiding catheter and only stent balloon was visible when it came out of the hub, leaving stent with little part floating in the left main (Figure 4). We pushed the wire further in order to ensure the wire remained inside the stent and tried to cross through the stent by small $1.25 \times 6 \mathrm{~mm}$ balloon, but it failed. We also tried to negotiate 0.014 " $190 \mathrm{~cm} \mathrm{Hi-Torque}$ BMW (Abbott Vascular, Santa Clara, USA) through the stent, but it failed as well. Finally, $2 \times 10 \mathrm{~mm}$ balloon was taken and parked parallel to the stent just inside the guiding tip (Figure 4C). The balloon was inflated to 13 atmospheres
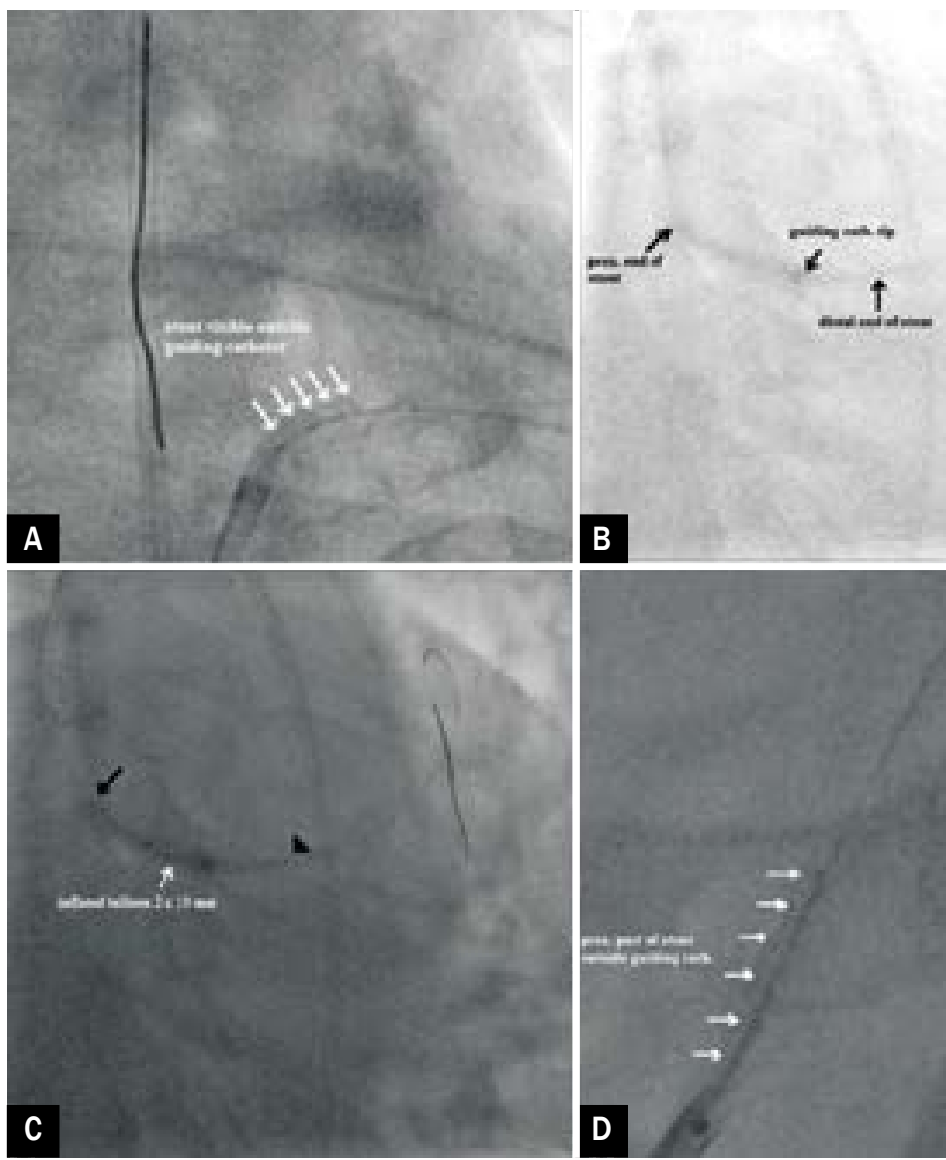

B

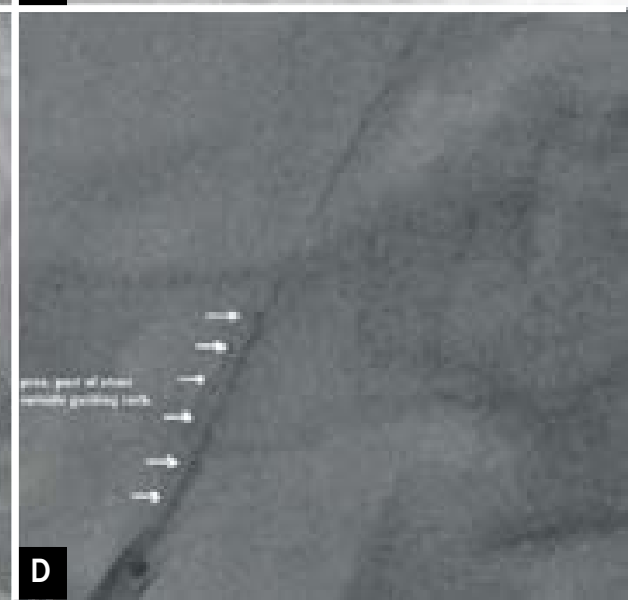

Figure 4A-D. Embolised stent hanging in left main (A, B); balloon placed parallel to stent in guiding (C); stent-balloon-guiding catheter wire i.e all being pulled as a unit (D) 


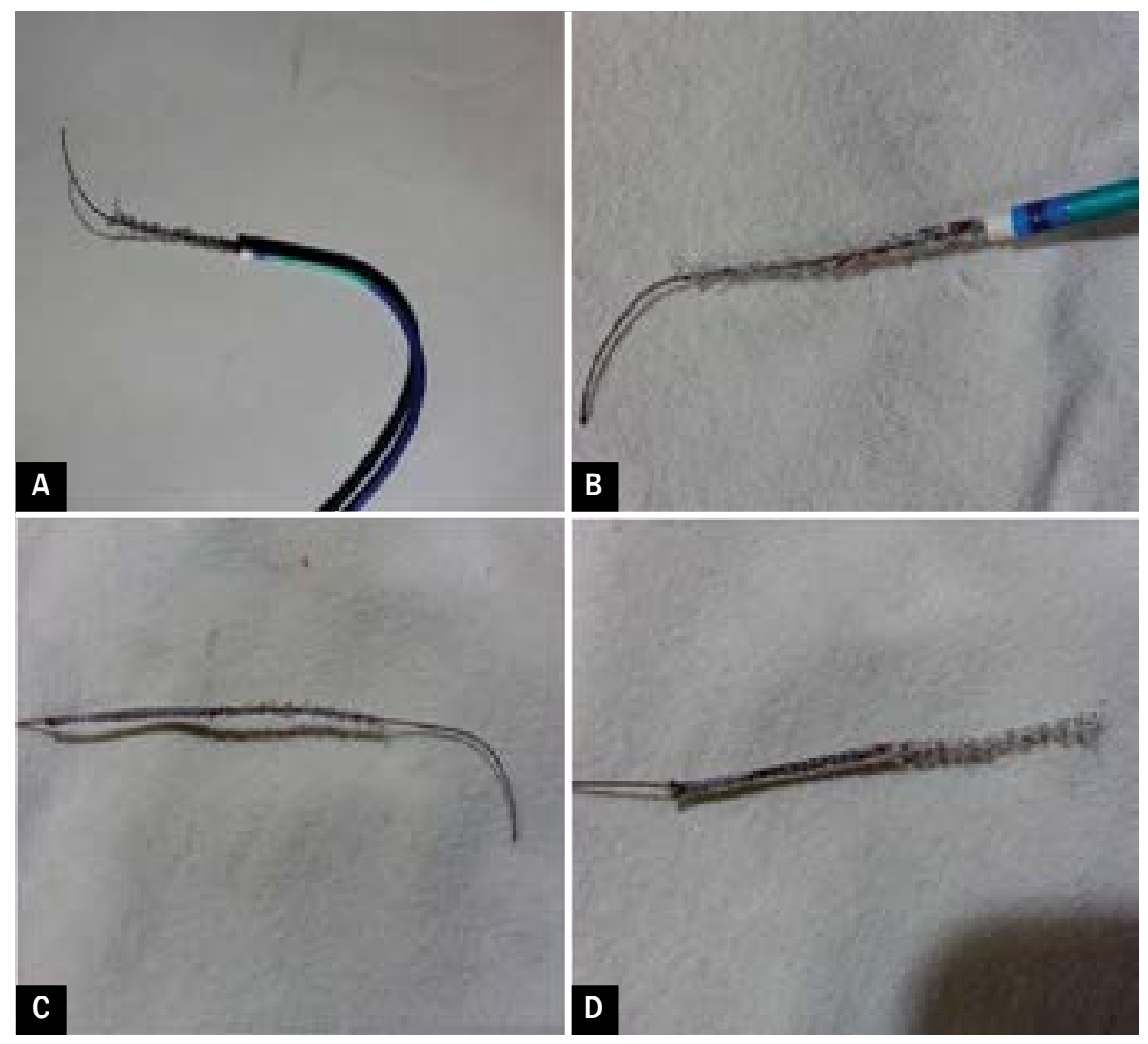

Figure 5A-D. Partially visible distorted struts being stuck at the mouth of the guiding catheter (A, B); only stent was beingover the wire (C, D)

and the stent-balloon-guiding catheter - wire i.e assembly as a unit was pulled under fluoroscopy and the stent was retrieved by trapping technique (Figure 4D, 5A-D). We re-crossed the total occlusion with a $0.014 " 190 \mathrm{~cm}$ Hi-Torque BMW (Abbott Vascular, Santa Clara, USA) and then further dilated the lesion with a $2.75 \times 10 \mathrm{~mm}$ cutting balloon. Two overlapping stents, proximally $3.5 \times 23 \mathrm{~mm}$ and distally $3 \times 19 \mathrm{~mm}$ were deployed successfully. Finally, it achieved Thrombolysis In Myocardial Infarction (TIMI) III flow (Figure 6). The patient was discharged after the third day and is under regular follow up since then.

\section{Discussion}

Stent embolisation is defined as the loss of the stent from the delivery system. It may occur proximal, in the lesion or distal to the lesion. If the guide is not co-axial and stability is not maintained, the guide may be displaced from the coronary ostium while the stent exits the guide and meets resistance in the coronary artery. The stent cannot be pushed further as there is no backup. While pushing the guiding or pulling the stent-balloon assembly, either of these manoeuvres may cause stent displacement and embolisation. This complication can be best avoided by choosing appropriate equipment: a low profile balloon-mounted

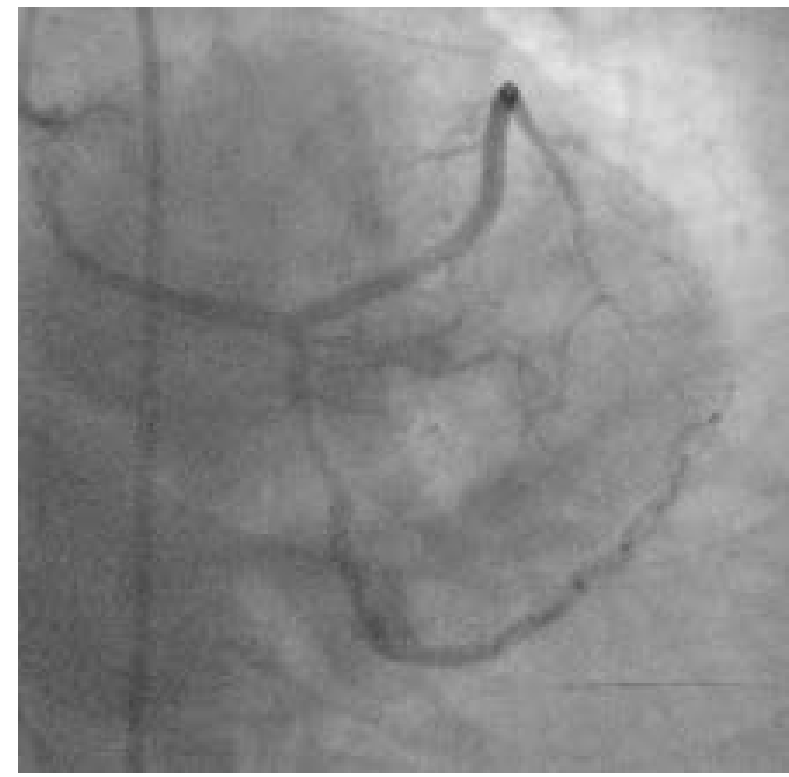

Figure 6. Anterior-posterior caudal view showing Thrombolysis In Myocardial Infarction (TIMI) III flow in left anterior descending (LAD) after deployment of two overlapping stents

stent that is well attached to the balloon, a co-axial guide catheter and possibly a stiffer wire that helps to straighten 
bends in the coronary artery and reduce resistance. However, the most important is to prevent this complication by taking utmost care while manipulating as the stent exits or re-enters the guide.

Unnoticed proximal coronary lesions, calcification, tortuosity, improperly prepared bed,very long stent or acute angulation may cause the stent to be held up or displace while it traverses the artery towards the target lesion [6]. Although third generation drug eluting stents are factory-mounted systems, the risk of stent embolisation has not been completely eliminated with incidence between 0.56 to $0.89 \%$ [7]. Stent dislodgement from the delivery system most often occurs when the stent balloon assembly is pulled back into the guiding catheter, or when the target lesion cannot be reached or cannot be passed due to unfavourable anatomy [8]. Intracoronary embolisation may cause dissection, thrombosis, perforation, arrhythmia, sudden death and systemic embolisation during the rescue attempts. Nevertheless, every possible effort at stent retrieval should be tried. If the stent is dislodged in the coronary artery, but is still on the guide wire, retrieval can often be achieved with a very low profile balloon inflated enough to secure the stent, which can be then withdrawn. The stent can either be secured by the balloon being inflated within it or just beyond it and gradually brought inside the guiding and then withdrawn. If a withdrawal of an embolised stent is not possible, the stent may be crushed by another stent while deployment. Other means of retrieving stents include commercially available goose-neck snares.

In our case, heavy calcification was a hurdle in preparing the vessel for stenting. Despite graduated predilation with four balloons, the vessel was still unprepared for stenting and instead of trying forceful placement we should have tried to predilate it with a bigger size balloon, whatwe finally did with upsize cutting balloon. However, lesions that cannot be dilated with conventional balloon catheters due to lesion rigidity may also be dilated with cutting balloon angioplasty (CBA) [9] and rotational atherectomy [10]. Though, one should not try to stent the poorly prepared artery. Fortunately, the stent was not dislodged around the coronary system and as soon as we observed the demounted stent at the guiding tip, we retrieved by simple trapping with help of a balloon. It was easy, convenient and cost saving as conventional snare was not used.

\section{Conflict of interest(s)}

None.

\section{Streszczenie}

Przemieszczenie stentu nowej generacji wydzielającego lek i związany z tym zator to bardzo rzadkie, lecz znane powikłanie przezskórnej interwencji wieńcowej, które może się wiązać z poważnymi następstwami. Opisywano różne metody chirurgicznego usunięcia stentu z życiem rozmaitych narzędzi endoskopowych, w tym narzędzi z końcówką w postaci splątanego drutu, szczypczyków biopsyjnych i pętli. W niniejszej pracy przedstawiono przypadek skutecznej ewakuacji zdeformowanego stentu wieńcowego z pnia lewej tętnicy wieńcowej techniką trappingu.

Słowa kluczowe: zakrzepica tętnic wieńcowych, zawał serca, usunięcie stentu, przemieszczenie stentu, zator, nagły zgon

Folia Cardiologica 2018; 13, 1: 39-43

\section{References}

1. Cishek M, Laslett L, Gershony G. Balloon catheter retrieval of dislodged coronary artery stents: a novel technique. Cathet Cardiovasc Diagn. 1995; 34(4): 350-352, doi: 10.1002/ccd.1810340216, indexed in Pubmed: 7621548.

2. McGinnity JG, Glazier JJ, Spears JR, et al. Successful redeployment of an unexpanded coronary stent. Cathet Cardiovasc Diagn. 1998; 44(1): 52-56, doi: 10.1002/(sici)1097-0304(199805)44:1<52::aidccd13>3.0.co;2-r, indexed in Pubmed: 9600524.

3. Eggebrecht H, Haude M, von Birgelen C, etal. Nonsurgical retrieval of embolized coronary stents. Catheter Cardiovasc Interv. 2000; 51(4): 432-440, doi: 10.1002/1522-726x(200012)51:4<432::aid-ccd12>3.0. co;2-1, indexed in Pubmed: 11108675.

4. Colombo A, Maiello L, Almagor Y, et al. Coronary stenting: single institution experience with the initial 100 cases using the Palmaz-Schatz stent. Cathet Cardiovasc Diagn. 1992; 26(3): 171-176, doi: 10.1002/ /ccd.1810260303, indexed in Pubmed: 1617707.

5. Elsner M, Peifer A, Kasper W. Intracoronary loss of balloon-mounted stents: successful retrieval with a 2-mm. Cathet Cardio- vasc Diagn. 1996; 39(3): 271-276, doi: 10.1002/(SICI)10970304(199611)39:3<271::AID-CCD13>3.0.C0;2-I, indexed in Pubmed: 8933971.

6. Norell MS, Perrins EJ. Essential interventional cardiology. $1^{\text {st }}$ edition. W.B. Saunders Company, China 2001: 86-87.

7. Yllmaz H, Belgi A, Demir I, et al. Successful transcatheter retrieval of an embolized stent from the left ventricle. J Invasive Cardiol. 2002; 14(8): 466-468, indexed in Pubmed: 12147879.

8. Holmes DRJr, Garratt KN, Popma J. Stent complications. J Invasive Cardiol. 1998; 10: 385-395.

9. Asakura $Y$, Furukawa $Y$, Ishikawa $S$, et al. Successful predilation of a resistant, heavily calcified lesion with cutting balloon for coronary stenting: a case report. Cathet Cardiovasc Diagn. 1998; 44(4): 420-422, doi: 10.1002/(sici)1097-0304(199808)44:4<420::aidccd13>3.0.co;2-m, indexed in Pubmed: 9716209.

10. Rosenblum J, Stertzer SH, Shaw RE, et al. Rotational ablation of balloon angioplasty failures. J Invasive Cardiol. 1992; 4(6): 312-318, indexed in Pubmed: 10147818. 